\title{
Contribution to the Development of Education Learning Design Christians and Budi Pekerti Based on Curriculum 2013 at Private School in the City of Ambon
}

\author{
Christiana Demaja W Sahertian \\ IAKN Lecturer in Ambon-Indonesia \\ mayasahertian@gmail.com
}

\begin{abstract}
The era of globalization has led to moral degradation and character. This degradation needs to be addressed through the formal education process in schools, especially Religion and Character education to protect students from this influence. This process is determined by the preparation of teaching through the creation of a Christian Religious Education Learning Implementation Plan (PAK) and Character. This process really helps teachers carry out teaching preparation that has an impact on students as subjects and objects of the process. The facts show that this process has not been able to help students to overcome these problems. For this reason, it is necessary to develop a special RPP for Christian Religion and Character education. This study aims to produce a design product for the implementation of Christian Religious Education and Character Education based on the 2013 curriculum at elementary schools in Ambon city and determine the impact of its application on the implementation of elementary school teacher duties in Ambon. This study used a research and development (R\&D) method involving PAK teachers and students at SD Negeri 24 Impres Skip, Ambon City, Sirimau District and SD Negeri 1 Suli, Baguala Ambon District as research subjects. The development research procedure is carried out in three stages, starting with the preliminary study stage, the development stage, and the model validation stage with a quasi experiment. In Model Testing, it is carried out in the form of limited testing and broader testing. The results of the lesson plan trial showed that the content substance and flexibility of the learning structure with a scientific approach could be understood by students. In addition, this system also makes it easier for teachers to plan, implement and evaluate learning optimally.
\end{abstract}

Keywords: Development of PAK and Budi Pekerti RPP, 2013 Curriculum

\section{Introduction section}

National education faces various problems. This problem will never be resolved because the substance that is transformed during the education and learning process is always under pressure from advances in science, technology, and the progress of society. One of them is the existence of an educational curriculum that is constantly changing. This change aims to improve the quality of national education, so that graduates have a competitive and comparative advantage in accordance with education quality standards, both at the national and international levels. In connection with curriculum changes, various parties analyzed and saw the need to apply a competency-based and character-based curriculum, which can equip students with various attitudes and abilities in accordance with the demands of the times and technology [1]. Within this framework, it is necessary to develop the 2013 Curriculum which 
is a continuation of the development of the Competency-Based Curriculum in 2004 and KTSP in 2006.

The 2013 curriculum is a Competency-based curriculum that began to be used and was determined to be a tool for delivering education for the first time in July 2013 in several pilot schools [2][3]. Determination by the government with the hope of overcoming problems and challenges, including: real competence needed by the world of work, globalization of the free market economy, building the quality of Indonesian people who have noble character, and become responsible citizens [4]. In Permendikbud No. 24 of 2014 that Curriculum Development 2013 is not only related to the issue of quality of education, but the quality of life of the Indonesian nation in general [5]. In addition, in the field of Christian Religious Education, this change is in line with the direction of changes in the dogmatically indocrinated into PAK to become PAK which frees students to develop dynamic spirituality that is visible through creative thinking, freedom in attitude and action in accordance with the contents of the teachings of the Christian faith [4][6].

Implementation of the 2013 Curriculum demands the readiness of teachers to be able to spearhead the successful implementation of the 2013 Curriculum [5]. Teachers need references that can guide them in implementing this curriculum. Because there are still many teachers who have not been able to design the implementation of learning according to the 2013 curriculum.

The results of preliminary observations and research were carried out by researchers for PPG teachers in 2014. This PPG was organized by STAKPN Ambon as the organizing institution for PPG for PAK teachers and Character in Indonesia. From the preliminary research, it was found that the teachers did not fully understand how to make learning designs and learning practices according to the provisions of the 2013 curriculum [4]. This observation is further emphasized by the results of the final evaluation of training activities, namely after conducting workshops and peer teaching, where $90 \%$ of them get "less" to "moderate" results so that it can be said that there is a significant effect if there is a curriculum change.

The results of the analysis carried out in several studies of the "Teacher's Book" and "Student Book" that the government has prepared as a complement to the 2013 curriculum, found that there is no continuity between the two books and the 2013 curriculum syllabus. This discontinuity is due to the two packages (Teachers' books and student books) have less material than the syllabus [4]. A syllabus is a learning plan in a group of subjects or a particular theme that includes competency standards, basic competencies, subject matter / learning, learning activities, competency achievement indicators for assessment, time allocation, and learning resources [5]. From this understanding it can be explained that student books and teacher books are development activities that must be based on the syllabus. However, this is not compatible.

Starting from this initial data, in my opinion, teachers need to prepare a lesson plan that can help and equip teachers and prospective teachers to be better in teaching preparation[7]. The learning implementation design itself according to Punaji[8] shows a systematic process of realizing the principles of learning and learning into planning materials and learning activities. This learning design is concerned with understanding, improving, and applying learning methods that are carried out by describing the processes or stages involved in learning planning. For this reason, the writing of this learning plan is prepared as an example to be able to help teachers and prospective teachers to be more capable in the learning process with the right steps in accordance with the provisions of the 2013 curriculum [9]. 
Based on this, the authors will develop a 2013 curriculum-based PAK learning implementation design which will be applied in accordance with a sound scientific approach For elementary schools. Therefore, this writing is directed at two issues, including:

a) Is the development of the 2013 curriculum-based learning design for PAK and Characteristics using the scientific approach for elementary schools in Ambon which the researcher designed was very good for teachers to use ?

b) What is the impact of the implementation of the 2013 curriculum-based PAK Learning Implementation Plan and Characteristics using a scientific approach on the implementation of elementary school teacher duties in Ambon?

\section{Theoritical Framework}

The development of learning designs is currently a hot topic discussed in various media, both print and electronic media by the government and education observers in this nation [10]. This is because the lesson plan (RPP) is a teacher's guide in teaching in front of the class. RPP is made to help teachers to comply with Competency Standards and basic competencies in the learning process. Therefore, the success of learning is largely determined by the skills of teachers in designing and developing the process of implementing learning in the classroom.

Less systematically designed learning will not show maximum results. Maximum results depend on the extent to which learning is designed and implemented properly and systematically. Good lesson planning will make it easier for teachers to carry out learning, while for students it will be more helpful and easier to follow the lesson. According to Punaji[8], the learning design shows a systematic process for realizing the principles of learning and learning into the planning of learning materials and activities. Learning design is concerned with understanding, enhancing, and applying learning methods. It is a systematic process for planning a learning system that is carried out by describing the processes or stages involved in learning planning.

According to Mulyana [11], the process of developing a learning implementation design is very important, because it can help teachers to think about learning before this lesson is taught, so that learning difficulties can be predicted and solutions can be found. In addition, the development of a learning implementation plan is based on ministerial regulation no 57/2014 [12], Minister of Education and Culture regulation No 22/2016 RPP 2013 revised curriculum version 2018 [13]. This grounding is in the hope that there will be a balance between soft skills (skills / personality competencies) and hard skills (skills / competencies in the field of science and technology) of students can be achieved, so that students are able to independently improve and use their knowledge, assess and internalize and personalize character values. and noble morals that are manifested in daily behavior.

\section{Method}

The type of research used is Research and development (R\&D) implementation design of PAK learning and character, the methodology used in this study uses research and development design ( $\mathrm{R} \& \mathrm{D}$ model). Research and development is a process used to develop and validate research products [14]. This R\&D development model is used, because this model is not only for developing products but also for finding new knowledge or to answer 
practical problems in education. The development research procedure is carried out in three stages, namely: Starting with a preliminary study stage that applies a qualitative descriptive approach ; The learning design development stage applies a descriptive approach, followed by a model trial by applying the experimental method (Single one shot case study). After there was an improvement from the limited test, a broader test was continued with the experimental method (one group pretest-posttest). Development to find new knowledge or to answer practical problems in the field and finally become the evaluation stage ; The model validation stage with quasi experiments (pretest-posttest with control group design) [15].

The research was conducted at SD Negeri 24 Impres Ambon in class I, with 38 students divided into 2 groups (Class 1 A and class 1b) and SD Negeri I Suli Ambon with 38 students for testing the developed model. Meanwhile, the impact test was used by PAK teachers. In Model Testing, it is carried out in the form of limited testing and broader testing.

First, Testing is limited to 24 Impres public SD, 2 (two) times of testing. The experimental method is a single one shot case study model. This experimental model is depicted as shown below:

\section{0}

$$
\begin{gathered}
\text { Inf. } X=\text { treatment in the form of applying the model } \\
\mathrm{O}=\text { Observation / results of applying the results }
\end{gathered}
$$

Second, a more extensive test was carried out at SD Negeri 1 Suli, each test 2 times, with the design method, one group pretest-postest which can be described as shown below:

\section{0}

Inf: $\mathrm{X}=$ treatment in the form of applying the model

$$
\mathrm{O}=\text { Final Test }
$$

\section{Results and Discussion}

\subsection{Discussion on Analysis of the development test of PAK and Character Learning Implementation in Elementary Schools in Ambon}

To test the form of model development, the researcher carried out two stages, namely: The first test was carried out at SD Negeri 24 Impres Ambon 2 times, namely: the first try in class Ia, The second try in class Ib. The experimental method is the Single One Shot Case Study model. This experimental model is depicted as shown below:

\section{\begin{tabular}{l|l}
$\mathbf{X}$ & $\mathrm{X}=$ treatment in the form of applying the model \\
$\mathrm{O}=$ Observation / results of applying the results
\end{tabular}}

For treatment in the form of the application of this model is carried out by means of a model that has been developed by researchers in the form of a learning implementation design that is applied in class Ia at SDN (state elementary school) 24 Impres Skip Ambon. The application is in the learning process carried out by PAK teachers and character for 23 class Ia children which are carried out on Fridays at 07.30-09.30 WIT, and 19 class Ib children which are carried out on Fridays at 10.00-12.30 WIT. Because in class Ia 23 and class Ib 19 people, 
so that there are data similarities and maintain data balance, the researcher uses 19 people in which class Ia is equated with Ib.

For observations / results from the application of the results, the data will be used from the 2013 curriculum application system with a scientific approach, namely: preliminary (initial) learning activities, core learning activities and closing learning activities. Core application consists of the process of observing, questioning, exploring, associating, communicating. The data from the results of these observations are the data used in the first trial results to see the steps of the scientific approach in the 2013 curriculum. Data from the limited trial results can be described in Table 1, below:

Table 1. Trial Data I

(SD Negeri 24 Inpres Skip Ambon in Ia class)

\begin{tabular}{|c|c|c|c|c|c|c|c|c|}
\hline \multirow{3}{*}{$\begin{array}{l}\text { No Responden } \\
\text { Class IA }\end{array}$} & \multicolumn{7}{|c|}{ Score for items } & \multirow{3}{*}{ Amount } \\
\hline & \multirow{2}{*}{$\begin{array}{l}\text { Prelimi-nary } \\
\text { active-ties }\end{array}$} & \multicolumn{5}{|c|}{ Core activities } & \multirow{2}{*}{$\begin{array}{c}\text { Closing } \\
\text { activities }\end{array}$} & \\
\hline & & M1 & M2 & M3 & M4 & M5 & & \\
\hline \multirow{3}{*}{19 Person } & 55 & 64 & 38 & 38 & 57 & 62 & 44 & 339 \\
\hline & $55 / 532$ & $64 / 532$ & $38 / 352$ & $38 / 532$ & $57 / 532$ & $62 / 352$ & $44 / 532$ & $338 / 532$ \\
\hline & 0.103 & 0.120 & 0.071 & 0.071 & 0.107 & 0.117 & 0.082 & 0.673 \\
\hline
\end{tabular}

Table 1. shows that of the 19 student respondents in class he obtained the amount of data $=$ 338. Thus the overall learning activity $=338: 532=0.673$ or $67 \%$. For testing in class $\mathrm{Ib}$, the 19 respondents can be explained in Table 2. below:

Table 2. Trial Data I

(SD Inpres24 Skip Ambon grade Ib)

\begin{tabular}{ccccccccc}
\hline No. Class & \multicolumn{7}{c}{ Score for items } & \\
\cline { 2 - 8 } $\begin{array}{c}\text { Responden } \\
\text { IA }\end{array}$ & $\begin{array}{c}\text { Prelimi-nary } \\
\text { active-ties }\end{array}$ & M1 & M2 & M3 & M4 & M5 & $\begin{array}{c}\text { Closing } \\
\text { activities }\end{array}$ & Amount \\
\hline \multirow{4}{*}{19 Orang } & 57 & 66 & 38 & 57 & 65 & 62 & 57 & 402 \\
& $57 / 532$ & $66 / 532$ & $38 / 532$ & $57 / 532$ & $65 / 532$ & $62 / 532$ & $57 / 532$ & $402 / 532$ \\
& 0.107 & 0.124 & 0.071 & 0.107 & 0.122 & 0.117 & 0.107 & 0.756 \\
& $11 \%$ & $12 \%$ & $7 \%$ & $11 \%$ & $12 \%$ & $12 \%$ & $11 \%$ & $76 \%$ \\
\hline
\end{tabular}

Table 2. describes the 19 student respondents in class Ib obtaining the amount of data $=$ 402. Thus the overall learning activity $=402: 532=0.756$ or $76 \%$. Based on Tables 1 and 2 , above, it can be seen that the average test value for the second trial (Table 2.) is greater than the first trial (Table 1.). This difference is illustrated in Figure 1 below.

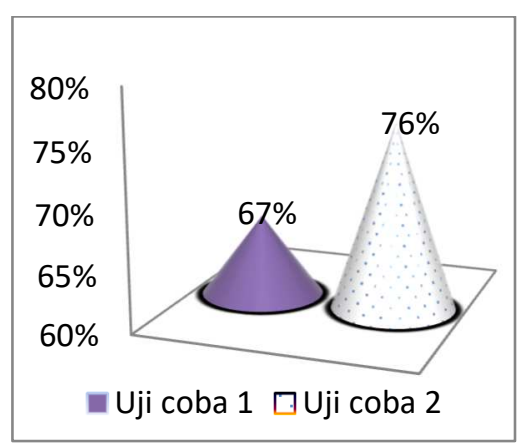

Fig.1. Difference in Trial of Limited Learning Design 
When implementing the learning activities the design used is the same in both learning activities. The difference in value can be said because the teacher in teaching presentations better understand the learning activities in accordance with the model that has been designed after being given an understanding related to learning activities in the first tryout in class Ia. Thus, the first test or limited test at SD 24 Impres Skip Ambon can be categorized as good in the application of PAK and Budi Pekerti learning design.

Second Test / Wider Testing. More extensive testing was carried out at Suli District I Primary School, Salahutu, Ambon 2 times, namely: the first trial in class I on August 13, 2014 at $08.00-09.45 \mathrm{Wit}$ with the same sub material, but there were some revisions to the changes in the steps of learning activities at the core namely the process of asking (M2) and exploring (M3). The second tryout on September 1, 2014 at 09.00-10.30Wit used different learning materials, but the steps in implementing the learning activities were made by taking into account the revision of the first (limited) trial. The second test uses a design method, the Single One Shot Case Study which can be described as shown below:

\section{0}

\section{$\mathrm{X}=$ treatment in the form of applying the model}

$$
\mathrm{O}=\text { Post Test }
$$

For treatment in the form of applying the revised learning implementation design model conducted by researchers carried out the same as in a limited test, with 30 samples of elementary school students grade I. Data on the results of extensive trials can be illustrated in Table 3. and Table 4. as follows.

Table 3. Broad Trial Data (SD Suli I KecSalahutu Ambon)

\begin{tabular}{|c|c|c|c|c|c|c|c|c|}
\hline \multirow{3}{*}{$\begin{array}{c}\text { No Class } \\
\text { Responden } \\
\text { IA }\end{array}$} & \multicolumn{7}{|c|}{ Score for items } & \multirow{3}{*}{ Amount } \\
\hline & \multirow{2}{*}{$\begin{array}{c}\text { Prelimi-nary } \\
\text { active-ties }\end{array}$} & \multicolumn{5}{|c|}{ Core activities } & \multirow{2}{*}{$\begin{array}{l}\text { Closing } \\
\text { activities }\end{array}$} & \\
\hline & & M1 & M2 & M3 & M4 & M5 & & \\
\hline 19 Person & $\begin{array}{c}66 \\
0.124\end{array}$ & $\begin{array}{c}71 \\
0.133\end{array}$ & $\begin{array}{c}61 \\
0.115\end{array}$ & $\begin{array}{c}66 \\
0.124\end{array}$ & $\begin{array}{c}67 \\
0.126\end{array}$ & $\begin{array}{c}67 \\
0.126\end{array}$ & $\begin{array}{c}65 \\
0.122\end{array}$ & $\begin{array}{c}463 \\
0.870\end{array}$ \\
\hline
\end{tabular}

Based on the data in Table 3., from 19 student respondents in class I obtained the amount of data $=463$. Thus the overall learning implementation activities $=463: 532=0.870$ or $87 \%$.

Table 4. Broad Trial Data

(SD I Suli Kec. Salahutu Ambon. September 1, 2014)

\begin{tabular}{|c|c|c|c|c|c|c|c|c|}
\hline \multirow{3}{*}{$\begin{array}{c}\text { No } \\
\text { Class } \\
\text { Respond } \\
\text { en I }\end{array}$} & \multicolumn{7}{|c|}{ Score for items } & \multirow[b]{3}{*}{ Amount } \\
\hline & \multirow{2}{*}{$\begin{array}{c}\text { Prelimi- } \\
\text { nary } \\
\text { active-ties }\end{array}$} & \multicolumn{5}{|c|}{ Core activities } & \multirow{2}{*}{$\begin{array}{l}\text { Closing } \\
\text { activities }\end{array}$} & \\
\hline & & M1 & M2 & M3 & M4 & M5 & & \\
\hline 19 & 76 & 72 & 70 & 73 & 69 & 71 & 76 & 507 \\
\hline Person & 0.143 & 0.135 & 0.1316 & 0.137 & 0.130 & 0.133 & 0.143 & 0.953 \\
\hline
\end{tabular}

Based on the data in Table 4., from 19 respondents students in class I obtained the amount of data $=507$. Thus the overall learning implementation activities $=507: 532=0.953$ or $95 \%$. 
Based on tables 3 and 4, the above shows that the average value of the trial, for the second trial (Table 3.) Is greater than the first trial (Table 4.). The difference is illustrated in Figure 2 below.

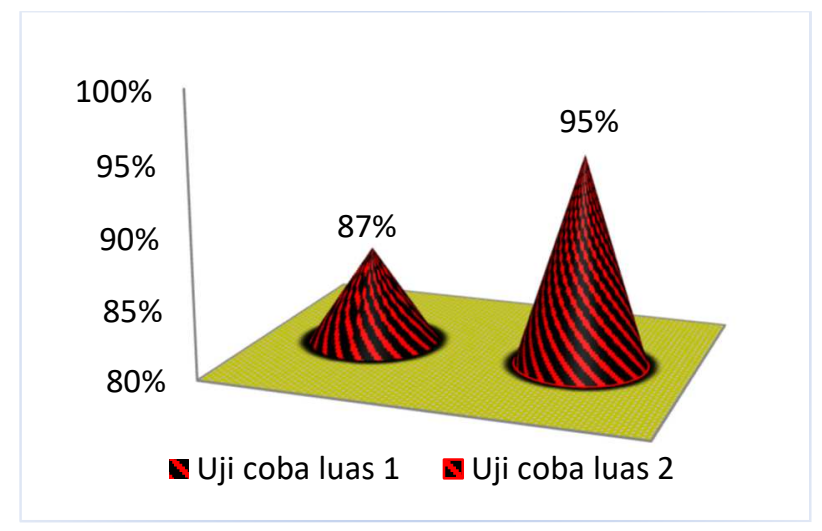

Fig.2. Differences in Broad Trials of Learning Designs

When implementing the learning activities the design used is a revised design with the same learning material. Improvements after the model testing activities are more emphasized in the core activities in the inquiring step (M2), in exploring (M3), and in communicating (M5). Thus, in the extensive trials conducted at Suli Ambon I Primary School I can be categorized very well in the application of floating PAK learning design and character. With this model, what is it said that PAK and CharacterLearning teachers can be used as models in implementing learning based on the 2013 curriculum? From the results of the study described above, it can be explained that:

a) The content content and flexibility of the learning structure for the five elements in the 2013 curriculum with a scientific approach starting from the implementation of initial activities, core implementation in the form of observing, asking, exploring, associating and communicating and implementing Finally, it can be understood by students and seen from the final observations stated in the teacher's assessment during the learning process.

b) The developed learning design model makes it easy for teachers to prepare 2013 curriculum-based learning plans, carry out learning and evaluate learning outcomes.

c) Improving student learning outcomes in the learning process. Data is addressed in tables 2 and 4.

4.2 The Impact of Developing the 2013 Curriculum-Based PAK and Budi Pekerti Learning Implementatio Design with a Scientific Approach for Elementary School Teachers in Ambon

\subsubsection{Support For Teachers}

Validation of the development of PAK learning designs and Characteristics, namely the impact of the application on the task of the teacher in compiling lesson plans, implementing learning, and developing assessment of learning outcomes in the learning process. In analyzing the implementation of the learning implementation design that is related to the aspects of the teacher's task, namely compiling lesson plans, implementing PBM and developing learning outcomes for the assessment of the learning process as an impact of the 
development of the 2013 curriculum-based RPP and Characteristics with a scientific approach for elementary school teachers which is support for teachers carried out in 2 stages.

Stage 1, conducted by researchers in socialization to elementary school teachers who also included junior and senior high school teachers participated in the 2013 curriculum training activities on 26-27 August 2014 at the Suli church, Salahutu district. Responses were given by 30 elementary school teachers by filling in the questionnaire given by the researcher. Stage 2, researchers in the activity of PAK teacher training training (PLPG PAK) which was held on 312 November 2014 followed by religious teachers from Papua, West Papua, Ambon, and Ternate as many as 210 people. This activity was attended by PAK teachers from SD, SMP and SMA. For the research purposes, the researcher used elementary school teachers to inform the data by filling out a questionnaire of 95 elementary school teachers.

\subsubsection{Data on the Impact of Implementing Learning Implementation Plans Against the Implementation of Elementary Teachers' Tasks in Kec. Salahutu}

Table 5. Impact of Implementing a Learning Implementation Plan Towards the Implementation of Elementary School Teachers' Kec. Salahutu

\begin{tabular}{|c|c|c|c|c|}
\hline \multirow[b]{2}{*}{ Task aspects } & \multicolumn{4}{|c|}{ Description of RPP Development Results } \\
\hline & Easy & Difficult & $\begin{array}{c}\text { Other } \\
\text { Responses }\end{array}$ & Amount \\
\hline \multicolumn{5}{|l|}{ 1. Develop RPP } \\
\hline $\begin{array}{l}\text { a. Develop lesson plans for } \\
\text { teaching }\end{array}$ & 26 & 2 & 2 & 30 \\
\hline $\begin{array}{l}\text { b. Developing the steps of } \\
\text { learning activities }\end{array}$ & 25 & 4 & 1 & 30 \\
\hline $\begin{array}{l}\text { c. Developing learning } \\
\text { outcomes assessment items }\end{array}$ & 26 & 3 & 1 & 30 \\
\hline Average (\%) & $77=25.67=86 \%$ & $9=3=10 \%$ & $4=1.33=4 \%$ & \\
\hline \multicolumn{5}{|l|}{ 2. Implement Learning Process } \\
\hline a. Application of observing & 23 & 5 & 2 & 30 \\
\hline b. Application of Asking & 25 & 4 & 1 & 30 \\
\hline \multirow{2}{*}{$\begin{array}{l}\text { c. Application of Exploring } \\
\text { d. The application of reasoning } \\
\text { / associating }\end{array}$} & 26 & 3 & 1 & 30 \\
\hline & 23 & 5 & 2 & 30 \\
\hline $\begin{array}{l}\text { e. Application of } \\
\text { Communicating }\end{array}$ & 25 & 4 & 1 & 30 \\
\hline Average $(\%)$ & $122=24.4=81.33 \%$ & $21=4.2=14 \%$ & $7=1.4=4.67 \%$ & \\
\hline \multicolumn{5}{|l|}{$\begin{array}{l}\text { 3. Carry out evaluation of } \\
\text { learning outcomes }\end{array}$} \\
\hline \multirow{2}{*}{$\begin{array}{c}\text { a. Implementing assessment of } \\
\text { learning outcomes in PBM } \\
\text { Average }(\%)\end{array}$} & 23 & 5 & 2 & 30 \\
\hline & $76.67 \%$ & $16.67 \%$ & $6.66 \%$ & \\
\hline
\end{tabular}

Table 5. illustrates the impact of the development of the 2013 Curriculum-based PAK Learning Implementation Plan and Characteristics based on a questionnaire given to 30 elementary school teachers in Ambon, in the 2013 curriculum socialization and training activities, 26-27 August 2014 at the Suli Church, Salahutu District. This impact on the implementation of tasks for elementary school teachers, namely $86 \%$ of teachers stated that compiling a lesson plan which included items: compiling lesson plans for teaching, developing steps for easy learning activities, and developing outcome assessment items. learn. 
To answer carrying out learning activities with items, namely the application of observing, the application of asking, the application of exploration, the application of reasoning and the application of communicating. The results are: $81.33 \%$ of teachers stated that implementing learning was easier, and $76.67 \%$ of teachers stated that in terms of evaluating learning it was easier.

4.2.3 Data on the Impact of Implementing the Learning Implementation Plan on the Implementation of the Tasks of the Ambon PLPG Elementary School Teachers

Table 6. Impact of Implementing a Learning Implementation Plan Towards the Implementation of the Tasks of Ambon PLPG Elementary School Teachers

\begin{tabular}{|c|c|c|c|c|}
\hline \multirow[b]{2}{*}{ Task aspects } & \multicolumn{4}{|c|}{ Description of RPP Development Results } \\
\hline & Easy & Difficult & $\begin{array}{c}\text { Other } \\
\text { Responses }\end{array}$ & Amount \\
\hline \multicolumn{5}{|l|}{ 1. Develop RPP } \\
\hline $\begin{array}{l}\text { a. Develop lesson plans for } \\
\text { teaching }\end{array}$ & 75 & 13 & 7 & 95 \\
\hline $\begin{array}{l}\text { b. Developing the steps of } \\
\text { learning activities }\end{array}$ & 71 & 20 & 4 & 95 \\
\hline \multirow{2}{*}{$\begin{array}{l}\text { c. Developing learning } \\
\text { outcomes assessment items } \\
\text { Average (\%) }\end{array}$} & 72 & 18 & 5 & 95 \\
\hline & $218=72.67=76.5 \%$ & $51=17=17.9 \%$ & $16=5.33=5.6 \%$ & \\
\hline 2. Implement Learning Process & & & & \\
\hline a. Application of observing & 82 & 9 & 4 & 95 \\
\hline b. Application of Asking & 75 & 14 & 6 & 95 \\
\hline \multirow{2}{*}{$\begin{array}{l}\text { c. Application of Exploring } \\
\text { d. The application of reasoning / } \\
\text { associating }\end{array}$} & 77 & 16 & 2 & 95 \\
\hline & 73 & 21 & 1 & 95 \\
\hline $\begin{array}{l}\text { e. Application of } \\
\text { Communicating }\end{array}$ & 79 & 14 & 2 & 95 \\
\hline Average (\%) & $386=77.2=81.26 \%$ & $74=14.815 .58$ & $15=3=3.16$ & \\
\hline \multicolumn{5}{|l|}{$\begin{array}{l}\text { 3. Carry out evaluation of } \\
\text { learning outcomes }\end{array}$} \\
\hline $\begin{array}{l}\text { a. Implementing assessment of } \\
\text { learning outcomes in PBM }\end{array}$ & 64 & 28 & 3 & 95 \\
\hline Average $(\%)$ & $64=67.37 \%$ & $28=29.47 \%$ & $3=3.16 \%$ & \\
\hline
\end{tabular}

Table 6. shows the impact of the development of the 2013 curriculum-based PAK Learning Implementation Plan and Characteristics in accordance with a questionnaire given to 95 elementary school teachers, in the 2014 PAK Teachers' PLPG activity, 3-12 November 2014 at Poka Ambon. This has an impact on the implementation of tasks for elementary school teachers, namely $76.5 \%$ of teachers stated that compiling a lesson plan which includes items: compiling lesson plans for teaching, developing steps for easy learning activities, and develop learning outcome assessment items. To answer implementing learning activities with items, namely the application of observing, the application of asking, the application of exploration, the application of reasoning and the application of communicating $81.26 \%$ of teachers stated that implementing learning was easier, and $67.37 \%$ of teachers stated that in terms of evaluation of learning it was easier. 


\section{Conclusion}

Based on the results of the analysis of research data it can be concluded that: 1) The development of the implementation of the 2013 curriculum and Character learning concept implementation using the scientific approach for elementary schools in Ambon can be used as an example for teachers to develop other RPPs according to education and class levels. 2) The Impact of Implementing the 2013 Curriculum-Based PAK and Character Learning Implementation Plan by using a scientific approach to the Implementation of Elementary School Teacher Tasks in Ambon is very good where the teacher is easy in preparing lesson plans, carrying out the process of learning activities and conducting evaluations.

\section{References and Citations}

[1] D. B. Kotan, "Kajian Pengembangan Kurikulum 2013; Mapel Pendidikan Agama Katolik dan Budi Pekerti," Jakarta, 2016.

[2] I. S. Irmadani, "Implementasi Kurikulum 2013 Mata Pelajaran Pendidikan Agama Islam di SD Swasta," ANSITU PAI, vol. Vol. 3, no. No.1 Januari-Juni, p. 46, 2019.

[3] Martiyono and Dkk, Mengelola dan Mendampingi Implementasi Kurikulum 2013. Jokjakarta: Aswaja Pressindo, 2014.

[4] C. D. W. Sahertian and R. Bawole, "Pembelajaran Pendidikan Agama Kristen dan Budi Pekerti Berbasis Kurikulum 2013; RPP di SD kota Ambon, Policy Brief JIKTI 2015,” Makasar, 2015.

[5] Kemendikbud, Permendikbud 24 tahun 2014. 2014.

[6] V. M. Fransiska and R. Napitupulu, Pendidikan Agama Kristen dan Budi Pekerti SD kelas II, Edisi II (. Jakarta: Pusat Kurikulum dan Pembukuan, Balitbang Kemendikbud, 2017.

[7] C. D. . Sahertian, "Materi Ajar Pengembangan RPP Model KTSP," Ambon: STAKPN Ambon, 2010.

[8] S. Punaji, Metode Penelitian Pendidikan dan Pengembangan. Jakarta: Jakarta Kencana, 2010.

[9] C. D. . Sahertian, "Pengembangan Rencana Pembelajarann (Materi Ajar)," Buku Ajar., Ambon: STAKPN Ambon, 2010

[10] Kemendikbud, "Kegiatan Pelatihan Kurikulum 2013 bagi Pengawas SMA Provinsi Jawa Barat."

[11] D. Mulyana and R. Jalalludin, ILMU KOMUNIASI SUATU PENGANTAR. Bandung: PT. Remaja Rosdakarya, 2005.

[12] Permendikbud, Salinan Permendikbud RI nomor 57 Tahun 2014. 2014.

[13] Permendikbud, Salinan Pemendikbud Nomor 22 Tahun 2016. 2016. 